http://kitaibelia.unideb.hu/

ISSN 2064-4507 (Online) • ISSN 1219-9672 (Print)

(C) Department of Botany, University of Debrecen, Hungary

23 (2): 188-196.; 2018

DOI: $10.17542 /$ kit.23.188

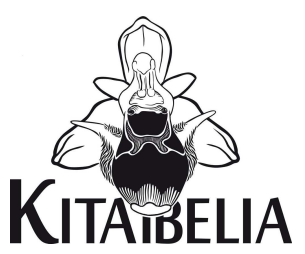

\title{
A Calamagrostis stricta (Timm) Koeler elterjedése a Dél-Nyírségben
}

\author{
DEMETER László \\ Hortobágyi Nemzeti Park Igazgatóság, H-4024 Debrecen, Sumen u. 2.; demeterlaszlo@hnp.hu \\ Distribution of Calamagrostis stricta (Timm) Koeler \\ in the Southern Nyírség (E Hungary)
}

\begin{abstract}
This study presents the current distribution of narrow small-reed (Calamagrostis stricta (Timm) Koeler) in the southern part of Nyírség (E Hungary). Beyond the efforts to confirm previously known occurrences, a high number of potential habitats were surveyed. Field work was carried out from late autumn to early spring taking advantage of the better perceptibility of dry foliage. The species was detected in 43 localities inside the boundary of 15 settlements, which considerably exceeded our expectations. Although most of the populations were quite small, in some cases their extent reached over $1000 \mathrm{~m}^{2}$. Populations around the settlements of Penészlek, Fülöp and Nyírábrány were the most frequent and the largest in size. The endangered status of the species is caused by the insufficient water supply of suitable habitats in the region. Besides habitat change, desiccation can also amplify the effect of anthropogenic disturbances (e.g. ploughing, fishpond development), which poses a further threat to populations.
\end{abstract}

Keywords: chorology, East Hungary, endangered plant species, habitat desiccation, small-reed

Összefoglaló - A közlemény a lápi nádtippan elterjedésének feltérképezésében a Dél-Nyírség területén az utóbbi évek során elért eredményeket mutatja be. A korábbról ismert előfordulási helyek ellenőrzésén túl számos potenciális élőhely átvizsgálására is sor került. A felmérések nagyobb részben késő ősztől kora tavaszig történtek, kihasználva a faj száraz levélzetének könnyebb észlelhetőségét. Összesen 15 település határában, 19 flóratérképezési négyzetben, 43 lelőhelyen sikerült kimutatni a lápi nádtippan előfordulását a vizsgált területen. A vártnál jóval több lelőhelyen került elő, azonban a régi adatok egy részét nem sikerült megerősíteni. Az állományok túlnyomó része igen kicsi, bár néhány esetben az $1000 \mathrm{~m}^{2}$-t elérő összefüggő gyepjei is előkerültek. A termőhelyek legnagyobb sűrűségét, s egyben a legnagyobb kiterjedésű állományokat Penészlek, Fülöp és Nyírábrány határában találjuk. A tapasztalt élőhelyi viszonyok az irodalmi adatoknak megfelelően alakultak. Az eredmények alapján a faj veszélyeztetett helyzetét leginkább a vízviszonyok megváltozása okozza. Legalább részben ez eredményezte, hogy a korábban leírt előfordulások egy részét nem sikerült megerősíteni. A szárazság az élőhelyek átalakulását okozza, és az antropogén zavarásoknak is utat nyithat.

Kulcsszavak: elterjedés, élőhely kiszáradás, Kelet-Magyarország, nádtippan, veszélyeztetett növényfaj

\section{Bevezetés}

A lápi nádtippant boreális hidegkori reliktumként tartjuk számon Magyarországon. Hazai elterjedésének súlypontja a Nyírségre esik, a Zalai-dombvidéken említett előfordulását az Új magyar füvészkönyv (PENKSZA in KIRÁLY 2009) már kérdőjelesen kipusztultként jelzi, BoRHIDI (2007) pedig a lápi nádtippanos (Carici-Calamagrostetum neglectae Soó 1938) kapcsán a Tapolcai-medencében „egykori” előfordulásként ír. Mindazonáltal a faj nyírségi adataiban sem 
bővelkedünk, Magyarország edényes növényeinek elterjedési atlasza (BARTHA et al. 2015) is csupán négy ponttal jelzi, ami persze részben a régi adatok pontos helyének beazonosítási problémáiból is ered. Jelen cikk ezen a helyzeten igyekszik javítani. A Hortobágyi Nemzeti Park Igazgatóság Természetvédelmi Őrszolgálatában végzett munka során lehetőségem nyílt arra, hogy a Nyírség déli részén felkeressem a növény korábban ismert lelőhelyeit, és számos új adatát is rögzítsem. Az irodalmi adatok többsége, - eltekintve a Nyírpilis, Újtanya (Soó 1934), Bátorliget (Soó 1932, 1938), és Piricse (JAKAB \& LESKU 1996) lelőhelyektől, - a Nyírség e délebbi részeiről származik.

\section{Anyag és módszer}

A kutatási terület a Dél-Nyírség kistájára terjedt ki, az alábbi települések határában: Álmosd, Bagamér, Debrecen, Fülöp, Hajdúbagos, Hajdúsámson, Hosszúpályi, Kokad, Létavértes, Mikepércs, Monostorpályi, Nyíracsád, Nyíradony, Nyírábrán, Nyírlugos, Nyírmártonfalva, Penészlek, Újléta, Vámospércs.

A faj keresésére elsősorban a Hajdúsági Tájvédelmi Körzethez tartozó védett területeken, Natura 2000 területeken, valamint a földművelési miniszter által tájékoztató listában kihirdetett úgynevezett ex lege védett láppal érintett területeken került sor 2013-tól 2018. március végéig. Pontosítottam és újra átvizsgáltam az irodalomban szereplő korábbi lelőhelyeket is. Eleinte a vegetációs időben kutattam a növény után, leginkább zsombékosokban. Később azonban a homogénebb, sűrűn gyepes foltjainak feltérképezésére jobban bevált a téli időszak. Ez annak köszönhető, hogy a lápi nádtippan hajszerűen hullámzó, és igen világos elszáradt levéltömege (1. ábra) már messziről észrevehető a magassásrétek sötétebb vagy a dárdás nádtippan eltérő habitusú állományaiban. Egy-egy jobb állapotban megőrződött buga egyébként még ilyenkor is fellelhető volt, egészen márciusig. A nagyobb összefüggő élőhelyek állományának feltérképezésében a Hajdúság-Dél-Nyírség Természetvédelmi Tájegység más természetvédelmi őrei is részt vettek. A GPS-szel rögzített részletes adatok a Hortobágyi Nemzeti Park Igazgatóság nyilvántartásába kerültek.

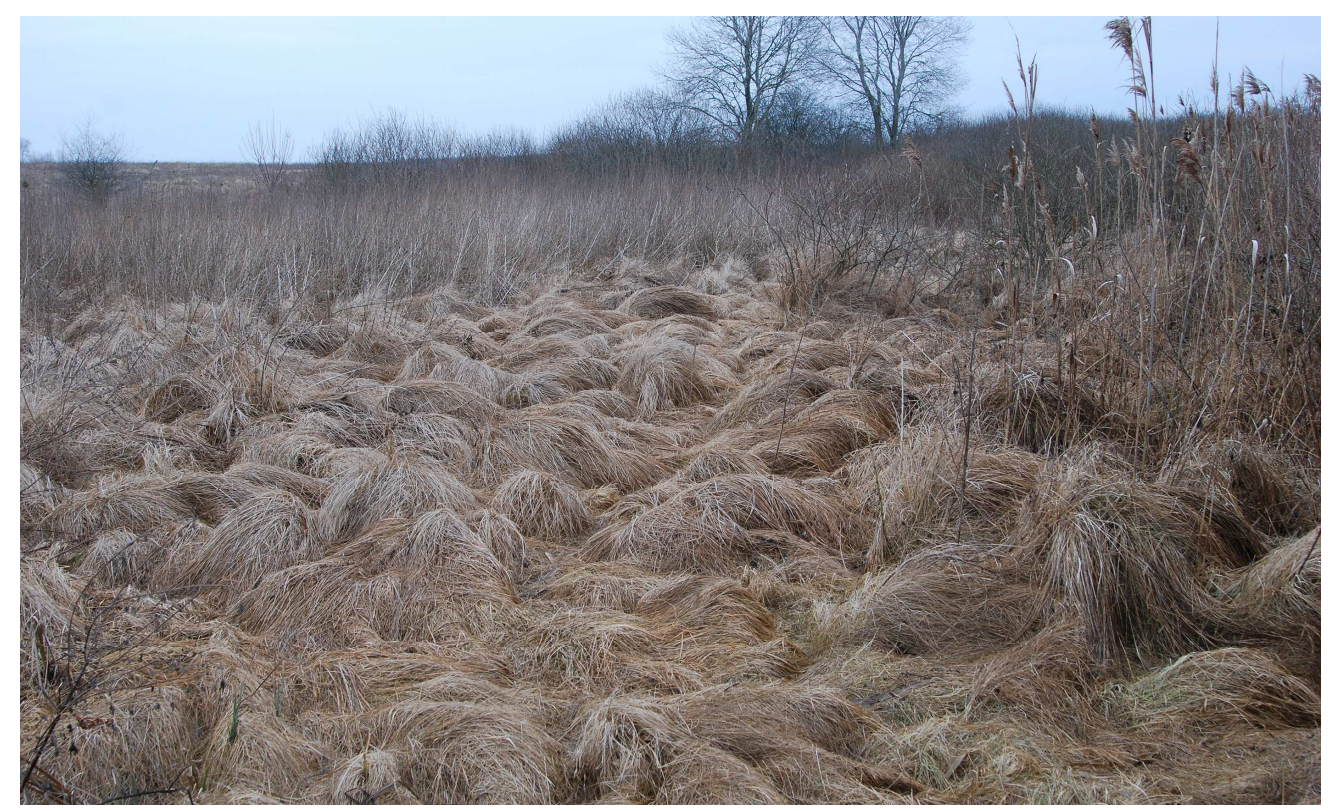

1. ábra. Nem zsombékoló lápi nádtippanos februárban

Fig. 1. Narrow small-reed stock without tussocks in February 
A lelőhelyek településhatáron belüli megnevezéséhez elsősorban a Magyarország Földrajzinév-tára térképét, valamint az 1:10 000 méretarányú topográfiai térkép helyneveit használtam. Helyenként zárójelben térképeken nem látható, de helyben használt neveket vagy a terület pontosítását szolgáló megjegyzéseket is feltüntettem. Szintén zárójelben adtam meg a megtalálás évét, és szögletes zárójelben az előfordulási helyet lefedő KEF-kvadrát kódját. A növényfajok nevei KIRÁLY (2009), a társulások elnevezése pedig BoRHIDI (2007) munkáját követi.

\section{A területről származó korábbi adatok áttekintése}

Soó $(1932,1938)$ a Debrecenhez tartozó Halápon a láprétek jellemző növényfajának nevezi a lápi nádtippant. A vizsgált területen belül említi még a debreceni „Bedecs”-ből, a Bagamérierdő lápjáról és a Penészlek határában található Peces-tóról (Soó 1934). Később a debreceni Pacról is leírja (Soó 1937). SIROKI (1970) Újléta közelében ad meg egy új lelőhelyet a létavértesi út mellett, említi még Debrecenben a Sámsoni út melletti lápot, és ő is felsorolja Halápot, Pacot, Penészleket és Bagamért. Érdekes, hogy a fenti publikációban Siroki nem említi a növény vámospércsi előfordulását, noha akkoriban már erről is tudhatott. A Debreceni Egyetem Herbáriumában ugyanis található négy példánya „Vámospércs zsombékos” lelőhely megnevezéssel és 1965. VI. 15-i dátummal. NAGY \& PAPP (1988) az Álmosd határában található Daru-lápról említi a fajt. PAPP \& DuDÁs (1990) Újlétán a Nagy-Ócsát és Csohos-tót, Nyírábrányban pedig a Nagyláprét és Láperdő előfordulási helyeket nevezi meg. PAPP et al. (1996/97) a penészleki Veres-rétről is leírta a növényt. Egy további lelőhely vált ismertté a debreceni Málik-tanyánál annak folytán, hogy KIRÁLY (2015) ebbe a taxonba tartozóként revideálta a MoLNÁR (2000) által Calamagrostis villosa (Chaix) J.F. Gmel.-ként közölt állományt.

A Debreceni Egyetem Herbáriumában számos példány található, túlnyomó részben az 1931-1974 közötti időszakból. A vizsgált területre eső termőhelyek között találjuk a debreceni Halápot, a Bedecs nevű területet, a Sámsoni út melletti lápot, Pacot, Újlétát, a penészleki Peces-tót, Bagamért, és a már említett Vámospércset. Az ezt követő időszakból mindössze 2 példány található Takács Attila gyűjtéséből, 2013-as évszámmal. Ez Penészlektől délre eső területről, minden bizonnyal a Veres-rétről származik. A herbáriumi adatok tehát - a vámospércsieket kivéve - mind az irodalmi lelőhelyeket erősítik meg.

\section{Eredmények}

\section{A korábbi előfordulások visszaellenőrzése}

Halápon a faj ma is megtalálható, annak ellenére, hogy SiROKI (1970) a lecsapolások miatt azt írja a halápi láprétről, hogy „már csak romja a réginek”. Ráadásul a 70-es évek elején a halápi lápok legmélyebb részeiből alakították ki a Halápi-, és Bodzás-víztározókat. A víztározókat összekötő csatorna mentén egy több száz négyzetméteres, részben zsombékoló állományt találtam, valamint kisebb foltokban előkerült a Halápi-tározótól északra elhelyezkedő láp keleti szegélyében is. A debreceni Bedecs helynevet nem sikerült pontosan azonosítanom. Eddig a paci előfordulási helyet sem tudtam azonosítani, és nem is sikerült megtalálnom a növényt azon a környéken.

A Bagaméri-erdő lápját a település közigazgatási határának legészakibb erdőtömbjében található Paprétnek feleltetem meg. Ezt támasztja alá az 1:10 000 méretarányú topográfiai térkép feliratozása, valamint a Szentannapuszta vasúti megálló közelsége, ami több botanikus számára is kiinduló pontul szolgált a környék bejárásához. Ez a láp ma rendszeresen kiszárad, ezért erősen degradálódik, zsombékosai pusztulnak. A fajt nem sikerült itt fellelnem. 
Előkerült viszont az innen fél kilométerre délnyugatra, a Konyári-Kálló nyílt völgyében elhelyezkedő Silye-rét lápjából. Persze, azt sem zárom ki, hogy esetleg ez lenne a „Bagaméri-erdő lápja".

A penészleki Peces-tónál ma is a vizsgált terület egyik legnagyobb lápi nádtippan állománya él. SIROKI (1970) Újlétához kötött helyszínét vélhetően sikerült beazonosítanom egy 1963-ben készült légi felvétel segítségével, az út nyugati oldalán. Az azonban közigazgatásilag Létavérteshez tartozik. Jelentősen átalakult, rendszeresen kiszárad, és kaszálását már régen felhagyták, mégis szálanként sikerült megtalálni egy Festuca pratensis Huds. uralta cserjés gyepfoltban. Az állomány minden bizonnyal a kipusztulás szélén áll. Tőle mintegy 800 méterre délre egy jóval erősebb állományra is rábukkantunk egy kiszáradt, csalánosodó zsombéksásosban.

Debrecenben a Sámsoni út mellett ma is megtalálható az említett lápfolt. Flórája azonban elszegényedett a kiszáradások miatt, és a lápi nádtippan többszöri átvizsgálás után sem került újra elő. A debreceni Málik-tanyánál élő apró állományt azonban sikerült fellelni.

Siroki vámospércsi gyüjtésének tényleges helyét nem tudom azonosítani, a fajt viszont a település északi és déli határában is megtaláltam egy-egy zsombékosban.

Az álmosdi Daru-láp Hajdúsági Tájvédelmi Körzethez tartozó két kaszálóján ma is él a növény.

PAPP \& DUDÁs (1990) által Újlétánál említett Nagy-Ócsát és Csohos-tót is igyekeztem alaposan átvizsgálni. Utóbbi valójában már Létavértes közigazgatási határához tartozik. Sajnos az elmúlt években egyik helyen sem sikerült megtalálnom az alkalmasnak látszó, de meglehetősen zegzugos élőhelyeken. Megkerülésére azonban az élőhelyek állapotát figyelembe véve látok esélyt. A nyírábrányi lelőhelyként megadott „Nagyláprét” és „Láperdő” ismereteim szerint a Káposztás-lapos és a Kis-mogyorós nevű határrészeknek felelnek meg, és a faj ma is előfordul mindkét területen.

A penészleki Veres-rét lápmedreiben az utóbbi években is jelentős állományait sikerült kimutatni.

Az új és megerősített előfordulások összesített listája

A csillaggal jelölt adatok a régi irodalmi említések megerősítései.

Álmosd

- *Daru-láp: két kisebb lápréti állomány, az egyik a Hieracium aurantiacum L. körül van. (2017) [8597.2].

Bagamér

- Silye-rét: láprét jellegű állományfoltok Calamagrostis canescens (Weber) Roth em. Druce között, máshol Carex cespitosa L. mellett, valamint rekettyés füzláp szegélyén, és egyéb magassásrétben (2016) [8497.4].

Debrecen

- *Haláp: a Bodzás-víztározót a Halápi-tározóval összekötő csatorna déli oldalán zsombékos és gyepes állományfoltok, a Halápi-tározótól északkeletre magassásrétben kis foltok (2015) [8496.4].

- *Soma: a Mártonfalvi út északi oldalán a Málik-tanya mellett néhány kis foltban (2015) [8497.1].

- Halápi-erdő (Erdész-lapos): kaszáló tisztáson Carex cespitosa és Salix rosmarinifolia L. mellett, valamint kicsit északabbra buckaközi mélyedésben Calamagrostis canescens-szel (2016) [8597.1].

- Bánki-erdő: rekettyés füzláp mellett, aranyvesszősödő magassásrétben (2016) [8596.2]. 
- Haláp-szél (a nyírmártonfalvi határ közelében, a Rauchbauer-erdő északnyugati oldalán): lápréti állomány Carex cespitosa-val és Carex appropinquata Schumach.-val vegyesen (2016) [8497.1].

- Nagycsere: a Derecskei-Kálló nyugati oldalágának partján 4 méter hosszú kis gyepje és néhány elszórt csomója került elő a 48. számú fóúttól északra, nyírfa ültetvény mellett (2018) [8496.4].

Fülöp

- Százholdas: Carex elata All. zsombékokon, valamint egy kaszált lápréten gyepes állományfoltok Carex cespitosa-val (2013) [8498.2].

- Tótfalu: zsombékokon és füzláp szegélyén gyepes állományban $(2014,2015)$ [8498.1].

- Nemes-tag: kevés zsombékon és 2-40 négyzetméteres gyepes foltokban (2015) [8398.4].

- Állatorvos-tag: kevés zsombék és 5-150 négyzetméteres gyepes foltok (2015) [8398.4].

- Petőfitelep: kisebb gyepes állomány (2015) [8398.4].

- Bogárzó: hajdan erdőtelepítésre barázdásan megművelt lápos területen sokszor több száz négyzetméteres gyepes foltokat alkot Calamagrostis canescens-szel váltakozva, valamint magassásrétben és nádas tisztásain (2015) [8398.3].

- Hunyadi-szállás: magassásrétben, kaszálókon sok nagy gyepes foltokat alkot, melyek között 1000 négyzetméteres kiterjedésű is van (2015) [8398.3].

- Csonka-dűlő: néhányszor 10 négyzetméteres gyepes állományfoltok (2016) [8398.1].

$\underline{\text { Kokad }}$

- Homoki-dűlő (Konyári-Kálló völgye): kisebb-nagyobb gyepes állományfoltok magassásrétben és Calamagrostis canescens között (2015) [8597.4].

Létavértes

- Mosonta-rét: füzlápban 2 zsombék és a szegélyben kis gyepes állomány $(2014,2015)$ [8697.1].

- *Kepecs-tag (az újlétai út mentén): kiszáradt hajdani lápréti kaszáló átalakult, cserjésedő gyepjében szórványos tövek, valamint délebbre nagyobb állomány kiszáradt zsombéksásosban (2016) [8597.3].

\section{Monostorpályi}

- Monostorpályi-legelő (északi részén, a Kis-Pályi-ér - Diószegi út keresztezése alatt): rekettyefüzes szegélyében szórványosan 20 négyzetméteren (2015) [8596.4].

Nyíracsád

- Jónásrész: lápréti kaszálón, rekettyés füzláp szegélyén szórványos állomány 12 négyzetméteren (2016) [8497.2].

Nyíradony

- Nagy-Póka: zsombékos és gyepes állományfoltok Carex elata zsombékosban és egyéb magassásrétben (2016) [8397.3].

\section{Nyírábrány}

- *Kis-mogyorós (Teleki-legelő): nagyobb gyepes foltokban és néhány Carex appropinquata zsombékon $(2013,2017)$ [8498.1].

- Dallárrész: három különálló területen Carex elata zsombékosban és kaszált lápréten (2013) [8498.1].

- Hanelek (Múlik-lapos): Carex elata zsombékokon és gyepes foltokban $(2013,2016)$ [8498.2].

- Kövendi-legelő: Carex elata zsombékokon gyakori $(2014,2015)$ [8497.4] 2016-ban ezen a helyen a zsombékokat kiforgatták és részben feltárcsázták a legnagyobb élőhelyet. 
- *Káposztás-lapos: kisebb lápréti foltok (2015) [8497.2].

- Keszler-tag: kisebb zsombékoló állomány nyírláp melletti lápréten (2016) [8498.1].

Nyírlugos

- Fülöpi-oldal: több száz négyzetméteres gyepes foltokban és kevés zsombékon is (2016) [8398.1].

Nyírmártonfalva

- Csizmaszár: néhány négyzetméteres gyepes állományfoltok rekettyés füzláp szegélyén (2016) [8497.1].

- Borisz-dúlő: gyepes állományfoltok kiszáradt, degradálódó, csalános láprétmaradványon Phalaris arundinacea L. mellett (2016) [8397.3].

- Stern-tag (a Bodzás-ér keleti oldalán): kisebb-nagyobb gyepes állományfoltok és néhány zsombék főleg Carex acutiformis Ehrh. és Carex riparia Curtis között, valamint ritkás nádasban (2017) [8497.1].

Penészlek

- Tápai-erdő: zsombéksáson szórványos az államhatáron átnyúló buckaközi mélyedésben (2013) [8399.3].

- *Veres-rét: gyepes állományok és zsombékokon is szórványos a kiterjedt lápmedrekben (2013, 2015, 2017) [8498.2] [8398.4].

- *Peces-tó: kiterjedt állományok főként nagy gyepes foltokban, de zsombékon, és ritkás nádasban is $(2014,2015)$ [8499.1] [8499.3] [8498.2].

- Pócsi-sziget: Carex elata zsombékokon szórványos, valamint néhány négyzetméteres foltokban gyepes állományok (2015) [8399.3].

- Dózer-tó menti lápok: nagyrészt gyepes habitusú állományfoltok kevés zsombékkal magassásrétben és rekettyés füzláp szegélyén (2016) [8398.4].

Újléta

- Hegyalja (Monostori-ér két oldalán): szórványos, illetve sűrün gyepes állományok füzesedő rétben és magassásréten (2015) [8597.1].

- Kapott-tag: rekettyés füzláp szélén szórványos 15 négyzetméteren (2015) [8597.1].

- Malomgáti-dúlő: néhány Carex elata zsombékon (2016) [8597.1]. Utóbbi előfordulást Szél László találta egy hatósági eljárás során. Az élőhely jelentős részéből földmunkával tavat alakítottak ki.

- Steiertag: 20-30 négyzetméteres gyepes foltokban egy Monostori-ér menti lápban (2016) [8597.1].

Vámospércs

- Bólya-dúlók (a Monostori-ér forrásági részén): rekettyés fúzlápban, Carex elata zsombékokon szórványos (2014) [8597.1].

- Nagynyíresdűlő (a Villongó-víztározótól északnyugatra egy árok mentén): 80 négyzetméteres gyepes állomány Carex elata zsombékok és Carex acutiformis között (2016) [8497.4]. Ezt az élőhelyet 2017-ben ledózerolták, és szántóként kezdték művelni.

Az érintett KEF-kvadrátok kódjainak összesített listája: 8397.3, 8398.1, 8398.3, 8398.4, 8399.3, 8496.4, 8497.1, 8497.2, 8497.4, 8498.1, 8498.2, 8499.1, 8596.2, 8596.4, 8597.1, $8597.2,8597.3,8597.4,8697.1$ 


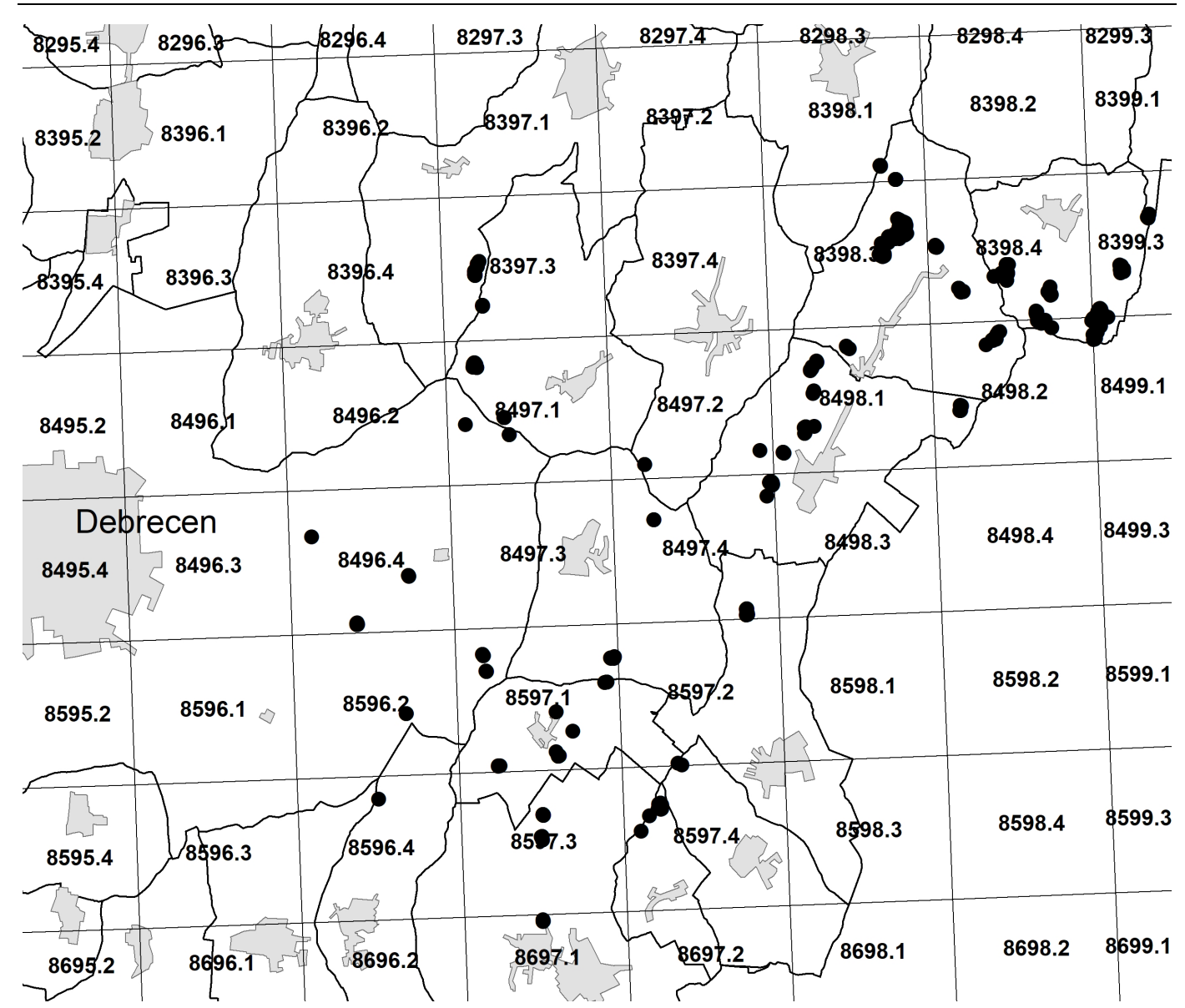

2. ábra. A lápi nádtippan (Calamagrostis stricta) elterjedése a Dél-Nyírségben a közép-európai flóratérképezés hálórendszerének (KEF) kvadrátjaival

Fig. 2. Distribution map of narrow small-reed (Calamagrostis stricta) in the southern part of Nyírség region, with the quadrates of the Central European flora mapping system (CEU)

Élőhelyi, társulástani viszonyok

PAPP in FARKAS (1999) a lápi nádtippan élőhelyét úgy foglalja össze, hogy zsombékosokban állomány- és társulásalkotó, ezenkívül zsombéksásosokban, magassásosokban, nádasokban, nedves kaszálókon, nyír- és füzlápokon található. Ezek közül a Dél-Nyírségben nyírláp belsejében még nem találkoztam vele, míg a többi élőhelyi típus előfordult.

BORHIDI \& SÁNTA (1999) a lápi nádtippanos (Carici-Calamagrostetum neglectae Soó 1938) társulás fiziognómiáját úgy jellemzi, hogy zsombékos vagy láprétszerú állományokat alkot. Dinamikájáról pedig megállapítja, hogy magassásos társulások (pl. Caricetum elatae Koch 1926, Caricetum acutiformis Eggler 1933) továbbfejlődése, illetve leromlása útján jön létre. Saját megfigyeléseim is illeszkedni látszanak ezekhez a megállapításokhoz. A mély vizű zsombékosokban a Carex elata zsombékjainak tetején, leggyakrabban csak kisebb csomókban fordult elő a nádtippan. Jó példa erre a nyírábrányi Kövendi-legelő, vagy a Hanelek nagy zsombékosa. Carex appropinquata zsombékokon csak néhány helyen észleltem. A rosszabb vízellátású, gyakran kiszáradó élőhelyeken a zsombékok oldalán is átvette az uralmat és megjelent a semlyékekben is. Sok példát lehetett látni arra is, amikor a sás már teljesen el- 
pusztult, az összeroskadt zsombékok púpjait és a köztük levő teret pedig egységesen a nádtippan sűrű gyepje borítja. A Soó (1938) által Bátorligetről leírt, Carex pseudocyperus-szal alkotott állományt ezen a vidéken nem találtam. A láprétszerű állományok leginkább homogén gyepes foltokat alkottak, melyek kiterjedése a néhánytól a mintegy ezer négyzetméterig terjedt. Gyakran magassásrétekben (főleg Caricetum acutiformis) voltak, vagy azokkal szomszédos kaszálók mélyebb részein. A legnagyobb kiterjedésű ilyen állományok Fülöpön a Bogárzó és Hunyadi-szállás lápján és rétjein, valamint a penészleki Peces-tónál figyelhetők meg. Az is előfordul, hogy dárdás nádtippanossal (Calamagrostetum canescentis Simon 1960) szomszédosan, vagy abba ágyazottam találjuk. Bagamérban és a Halápi-erdőben gyepes sással (Carex cespitosa) együtt is előfordul. Bagamérban kékperjés és magassásrét közötti zónában is találtam. Ritkás, alacsony nádasban a penészleki Peces-tónál, a fülöpi Bogárzón és a nyírmártonfalvi Stern-tagban figyeltem meg. Fűzlápoknál a cserjés szegélyén, illetve a felnyílt részeken fennmaradt zsombékokon fordult elő a növény.

\section{Összegzés és természetvédelmi vonatkozások}

Összesen 15 település határában, 19 flóratérképezési négyzetben, 43 lelőhelyen sikerült kimutatni a lápi nádtippan előfordulását a vizsgált területen. Az általam előzetesen vártnál jóval több termőhelyen találtam meg a növényt. Ez azt sugallhatja, hogy hasonló ráfordítással a Nyírség északabbi részein is számos megkerülésre számíthatnánk. Az állományok túlnyomó része azonban igen kicsi, gyakran csak néhány négyzetméterre vagy néhány zsombékra korlátozódik egy-egy elszigetelt buckaközi mélyedésben. A termőhelyek legnagyobb sűrüségét, $\mathrm{s}$ egyben a legnagyobb kiterjedésủ állományokat Penészlek, Fülöp és Nyírábrány határában találtam.

A faj veszélyeztetett helyzetét leginkább a vízviszonyok megváltozása okozza. Legalább részben ez az oka annak, hogy a korábban leírt előfordulások egy részét nem sikerült megerősíteni. A Nyírség csatornázása a XIX. század végén indult. A lápi élőhelyek zsugorodása vélhetően azóta folyik. Az utóbbi években olyan vízhiány jellemzi a térséget, hogy néhány különleges kivételtől eltekintve a lápmedrek mintegy 4 éve szárazak, és ezen a 2017-18-as évek átlagosnak tekinthető csapadékviszonyai sem tudtak enyhíteni. A szárazság az élőhelyek átalakulása mellett utat nyithat a közvetlen emberi pusztításnak is. Jól példázzák ezt az utóbbi években ledózerolt, feltárcsázott, felszántott, valamint intenzíven legeltetett termőhelyek. A szárazság másrészt felkelti az emberek nyílt vízterek iránti igényét is, ami esetenként a természetes mélyedések mesterséges kimélyítéséhez, átalakításához vezet. Így jöttek létre Haláp lápjai helyén a víztározók, napjainkban pedig a kisebb magán horgásztavak.

\section{Köszönetnyilvánítás}

Köszönet Szél Lászlónak a cikkhez átengedett újlétai adatáért. Köszönöm továbbá több nagyobb állomány részletes, közös feltérképezésében végzett munkáját Szél Lászlónak, Lisztes Annának és Monori Györgynek. Köszönöm Takács Attilának a herbárium áttekintésében nyújtott segítségét, valamint Matus Gábor és Penksza Károly lektori munkáját. 


\section{Irodalom}

Bartha D., Király G., Schmidt D., Tiborcz V., Barina Z., Csiky J., Jakab G., LeSku B., Schmotzer A., Vidéki R., Vojtкó A. \& Zólyomi Sz. (szerk.) (2015): Magyarország edényes növényfajainak elterjedési atlasza. Nyugat-magyarországi Egyetem Kiadó, Sopron, p. 304.

BoRHIDI A. \& SÁNTA A. (szerk.) (1999): Vörös Könyv Magyarország növénytársulásairól 1. TermészetBúVÁR Alapítvány Kiadó, Budapest.

BorHidi A. (2007): Magyarország növénytársulásai. - Akadémiai Kiadó, Budapest.

JАКAB G. \& LESKU B. (1996): Egy újabb ősláp a Nyírségben: A piricsei Júlia-liget botanikai értékei I. Kitaibelia 1: 46-55.

KIRÁLY G. (szerk.) (2009): Új magyar füvészkönyv. Magyarország hajtásos növényei. Határozókulcsok. Aggteleki Nemzeti Park Igazgatóság, Jósvafő.

KIRÁLY G. (2015): (18) Calamagrostis villosa (Chaix) J. F. Gmelin (Poaceae). In: BARINA et al.: Taxonomical and chorological notes 1 (1-19). - Studia botanica hungarica 46 (2): 205-221.

Molnár A. (2000): Calamagrostis villosa (Chaix) Gmel. Debrecen mellett. - Kitaibelia 5: 229-230.

NAGY M. \& PAPP M. (1988): Cönológiai és vegetációdinamikai vizsgálatok nyírségi gyepekben. - I. Magyar Ökológus Kongresszus. Elő́adás-kivonatok és poszter-összefoglalók, Budapest, p. 131.

PAPP L. \& DuDÁs M. (1990): Adatok a Közép-, a Dél-Nyírség és környékének botanikai értékeiről III. Calandrella 4: 5-33.

PAPP L. (1999): Calamagrostis stricta (Timm.) Koeler - Lápi nádtippan. - In: FARKAS S. (szerk.), Magyarország védett növényei. Mezőgazda Kiadó, Budapest, p. 343.

PAPP M., HAMVAS-MiKó M. \& NAGY M. (1996/97): Floristical and phytocoenological studies on the pasture of village Penészlek (Northeast Hungary). - Acta Botanica Hungarica 40 (1-4): 167-192.

PEnKSZA K. (2009): Calamagrostis Roth - Nádtippan. - In: KIRÁlY G. (szerk.), Új magyar füvészkönyv. Magyarország hajtásos növényei. Határozókulcsok. Aggteleki Nemzeti Park Igazgatóság, Jósvafö, p. 529.

SiroKi Z. (1970): A lápi nádtippan Calamagrostis neglecta (Ehrh) G.M. Sch. új lelőhelye és elterjedése a Nyírségen. - A Debreceni Déri Múzeum 1968. évi Évkönyve, pp. 15-20.

Soó R. (1932): Debrecen növényvilágának kutatása (Újabb adatok Hajdúmegye flórájának ismeretéhez.). - Debreceni Szemle 6: 216-225.

Soó R. (1934): Nyírség-kutatásunk florisztikai eredményei. - Botanikai Közlemények 31 (5-6): 218-252.

Soó R. (1937): Pótlékok Nyírségi flórakutatásunk eredményihez. - Botanikai Közlemények 34 (1-2): 1-12.

Soó R. (1938): Vízi, mocsári és réti növényszövetkezetek a Nyírségben. - Botanikai Közlemények 35 (5-6): 249-273.

Beérkezett / received: 2018. 08. 06. • Elfogadva / accepted: 2018. 10. 07. 
DEMETER L. (2018):

A Calamagrostis stricta (Timm) Koeler elterjedése a Dél-Nyírségben / Distribution of Calamagrostis stricta (Timm) Koeler in the Southern Nyírség (E Hungary)

Kitaibelia 23 (2): 188-196.

DOI: 10.17542/kit.23.188

\section{Elektronikus melléklet / Electronic appendix}

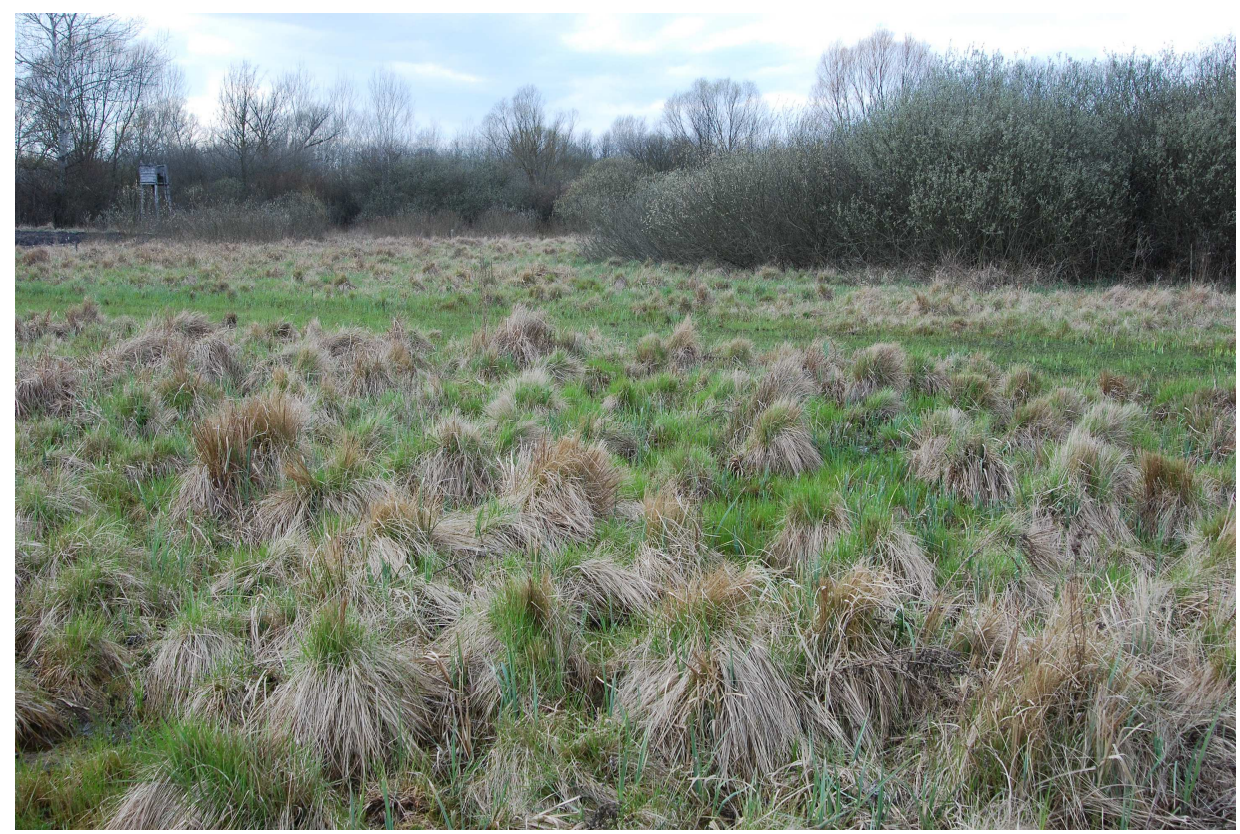

1. ábra. Gyengén legeltetett lápi nádtippan zsombékos Halápon

Fig. 1. Slightly grazed narrow small-reed tussocks in Haláp

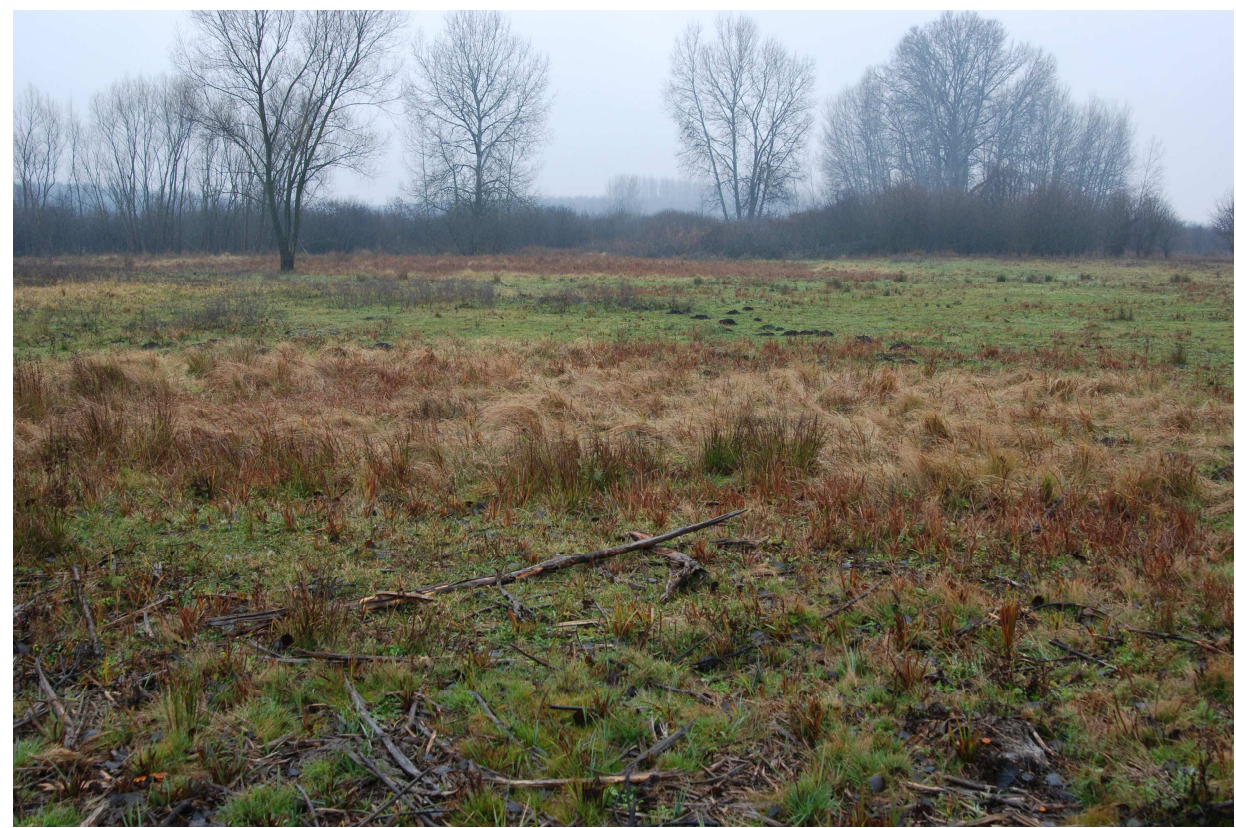

2. ábra. Kiszáradt és erősen legeltetett lápi nádtippan élőhely Kokadon Fig. 2. Dry narrow small-reed habitat under intensive grazing in Kokad 